\title{
SNOW-MEDIATED PTARMIGAN BROWSING AND SHRUB EXPANSION IN ARCTIC ALASKA
}

\author{
Ken Tape ${ }^{1}$, Rachel Lord ${ }^{1}$, H. P. Marshall ${ }^{2}$, and Roger W. Ruess ${ }^{1}$ \\ ${ }^{1}$ Institute of Arctic Biology, University of Alaska, \\ 902 N. Koyukuk Drive, Fairbanks, AK 99775, USA. \\ ${ }^{2}$ Center for Geophysical Investigation of the Shallow Subsurface, \\ Boise State University, Boise, ID 83725-1536, USA.
}

EXTENDED AbstRACT.-Large, late-winter ptarmigan migrations heavily impact the shoot, plant, and patch architecture of shrubs that remain above the snow surface (Tape et al. 2010). Willow Ptarmigan (Lagopus lagopus) browsing on arctic shrubs was assessed in the vicinity of Toolik Lake, on the north side of the Brooks Range in Alaska. Data were collected in early May 2007, at maximum snow depth, after the bulk of the ptarmigan migration had passed through the area. In an area of tall shrubs, half of the buds on Salix alaxensis were browsed by ptarmigan. Three percent of the buds that were buried beneath the snow were browsed, $90 \%$ of the buds that were less than $30 \mathrm{~cm}$ above the maximum snow level were browsed, and $45 \%$ of the buds above that height were browsed (Figure 1). Ptarmigan browsing was found to control shrub architecture by brooming stems at the snow surface and inducing stump shoots. These results were qualitatively extrapolated by photographing shrub morphology over a region approximately $300 \mathrm{~km}$ wide across a series of northflowing arctic rivers with headwaters in the Brooks Range. Ptarmigan "hedging" shrub patches, and shrub growth under a warmer climate, are opposing factors mediated by snow distribution. We speculate that the documented increase in shrubs (Figure 2, Tape et al. 2006), which constitutes critical late-winter ptarmigan forage, may be increasing ptarmigan populations. Increases in ptarmigan population dynamics would likely improve conditions for predators (other factors notwithstanding), including Gyrfalcons (Falco rusticolus), which could moderate or eliminate any increases in ptarmigan populations.

Circum-arctic research on shrub dynamics suggests that, where warming has occurred, photosynthetic activity has increased and shrubs have grown more rapidly and expanded their range (Forbes et al. 2010, Goetz et al. 2005, Tape 2010). Ptarmigan-Gyrfalcon dynamics contained in these proceedings and presented at the corresponding meeting, in general, did not indicate a similarly widespread increase in ptarmigan or Gyrfalcon abundance. Model results contained in these proceedings suggest that Willow Ptarmigan populations in Alaska should decrease with continued warming, as the ptarmigan's current environmental envelope decreases in area (Booms et al. 2011). Future work will be focused on reconciling projected decreases in ptarmigan populations with the increased availability of late-winter shrub forage. Received 8 March 2011, accepted 15 April 2011. 


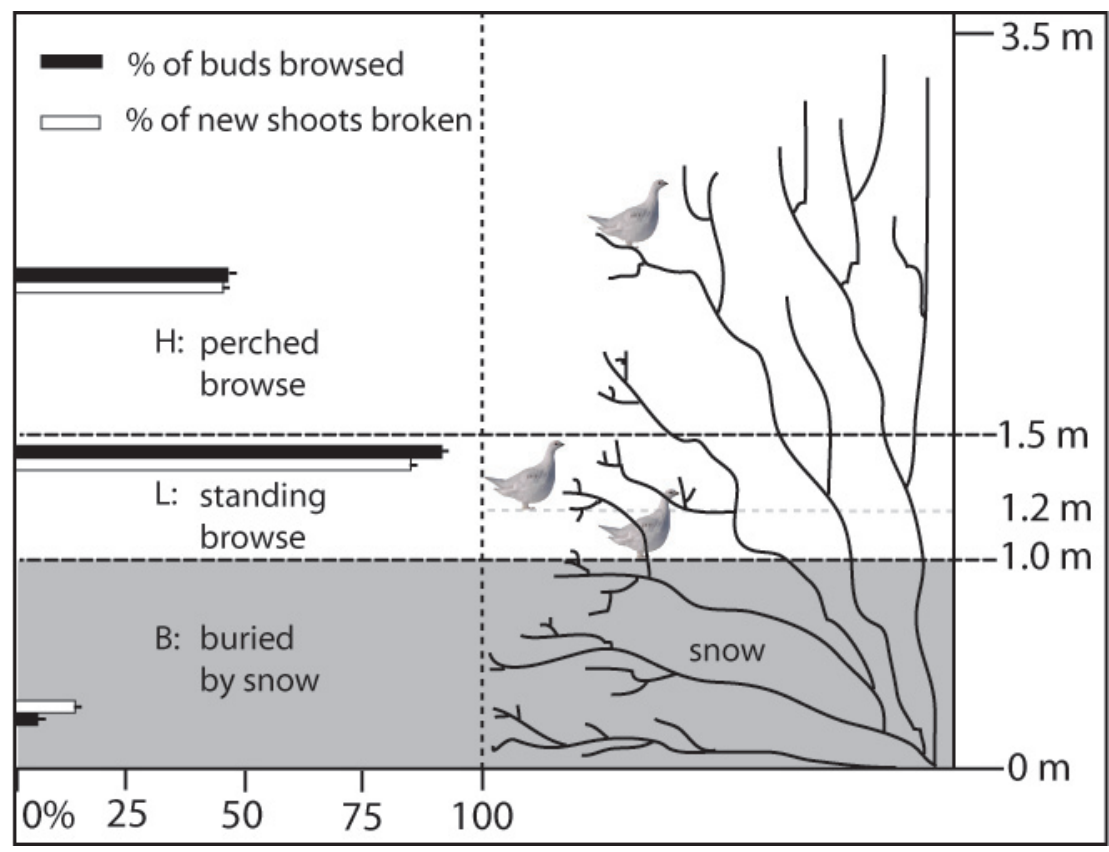

Figure 1. Relationship between ptarmigan browsing intensity and snow depth, with most intense browsing occurring $<50 \mathrm{~cm}$ above the snow.

TAPE, K., R. LoRd, H. P. MARshall, AND R. W. Ruess. 2011. Snow-mediated ptarmigan browsing and shrub expansion in arctic Alaska. Extended abstract, pages 221-224 in R. T. Watson, T. J. Cade, M. Fuller, G. Hunt, and E. Potapov (Eds.). Gyrfalcons and Ptarmigan in a Changing World, Volume I. The Peregrine Fund, Boise, Idaho, USA. http://dx.doi.org/10.4080/gpcw.2011.0118

Key words: Birch, browsing, climate, expansion, Green Alder, shrub, snow, ptarmigan, willow.

\section{Literature Cited}

Booms, T., M. Lindgren, And F. Huetmann. 2011. Linking Alaska's climate, Gyrfalcon, and ptarmigan distributions in space and time from 1900-2100. In R. T. Watson, T. J. Cade, M. Fuller, G. Hunt, and E. Potapov (Eds.). Gyrfalcons and Ptarmigan in a Changing World. The Peregrine Fund, Boise, Idaho, USA.

Forbes, B. C., M. M. Fauria, And P. ZetterBERG. 2010. Russian Arctic warming and 'greening' are closely tracked by tundra shrub willows. Global Change Biology 16:1542-1554.

Goetz, S. J., A. G. Bunn, G. J. Fiske, And R. A. Houghton. 2005. Satellite-observed photosynthetic trends across boreal North America associated with climate and fire disturbance. Proceedings of the National Academy of Sciences of the United States of America 102:13521-13525.

TAPE, K. D. 2010. The Changing Arctic Landscape. University of Alaska Press, Fairbanks, Alaska, USA.

TAPE, K. D., R. LORD, H. P. MARShall, AND R. W. RUESS. 2010. Snow-mediated ptarmigan browsing and shrub expansion in arctic Alaska. Ecoscience 17:186-193.

TAPE, K. D., M. Sturm, AND C. Racine. 2006. The evidence for shrub expansion in northern Alaska and the pan-Arctic. Global Change Biology 12:686-702. 


\section{- PtARMIGAN BROWSING AND SHRUB EXPANSION -}
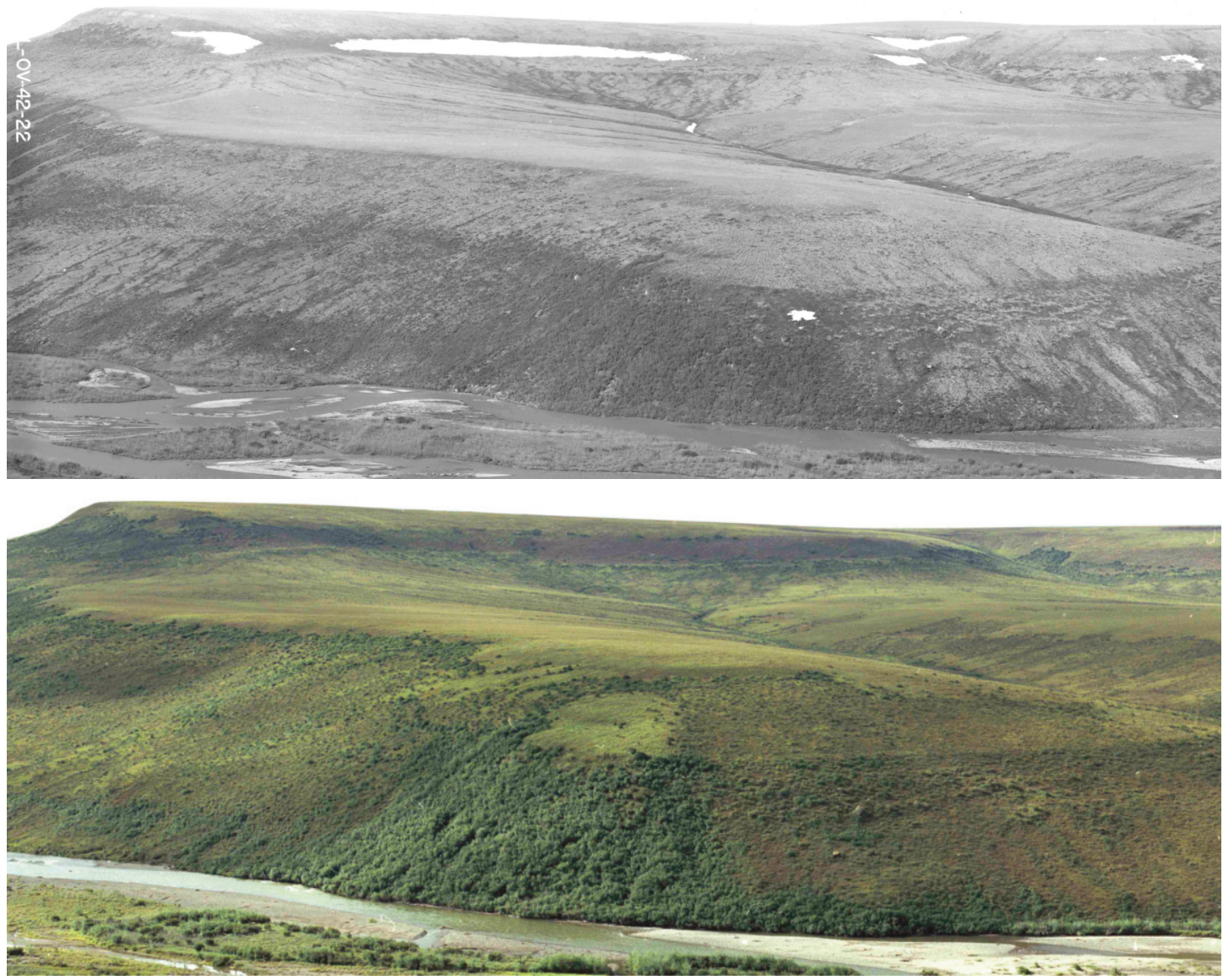

Figure 2. Old (4 July 1948) and new (28 July 2001) photographs along the Chandler River, showing obvious increases in Green Alder (Alnus viridis subsp. fruticosa) and less obvious increases in willow (Salix spp.) and birch (Betula spp.) shrubs. 
- TAPE ET AL. - 